\title{
Which electrode? A comparison of four endoscopic methods of electrocoagulation in experimental bleeding ulcers
}

\author{
C P SWAIN, T N MILLS, E SHEMESH, JULIA M DARK, M R LEWIN, \\ J S CLIFTON, T C NORTHFIELD, P B COTTON, AND P R SALMON
}

From the Departments of Gastroenterology, University College Hospital, St James' Hospital and the Middlesex Hospital; The Department of Medical Physics and Bioengineering at University College Hospital, London

SUMMARY Several inexpensive endoscopic methods of electrocoagulation have been advocated for treatment of gastrointestinal haemorrhage. We compared four types of electrode: dry monopolar - Cameron Miller (M), liquid monopolar - Storz (L), bipolar - Bicap ACMI (B), and heater probe - Seattle $(\mathrm{H})$. The electrical and thermal properties of these probes were studied using computerised monitoring of energy deposition and their efficacy and safety was tested in a randomised study in 140 experimental canine gastric ulcers. At optimal pulse settings 20J (M), $70 \mathrm{~J}(\mathrm{~L}), 17 \mathrm{~J}(\mathrm{~B}), 15 \mathrm{~J}(\mathrm{H})$, effective haemostasis was achieved in all ulcers, the mean number of pulses being M5, L6, H6 and B11, the first three requiring significantly $(\mathrm{p}<0.01)$ less pulse than B. Relative safety of the electrodes was assessed by comparing the incidence of full thickness damage at histology: B24\%, $\mathrm{H} 20 \%$, L58\% and $\mathrm{M} 69 \%$; B and $\mathrm{H}$ proving significantly $(\mathrm{p}<0.01)$ safer than $L$ and $M$. Sticking was assessed as $H>B>M \gg L$. Insensitivity to extreme angulation and force of application was assessed as $L>B>M(H$ is preset). Of the two safer electrodes the heater probe was more effective than the bipolar probe. Despite its greater tendency to stick than the other devices, the heater probe appeared the most promising of the endoscopic electrodes tested.

Endoscopic electrocautery for the control of gastrointestinal bleeding appears attractive as it is inexpensive when compared with the rival technique of laser photocoagulation, is easy to use and appears effective in controlled animal studies and uncontrolled human studies.

Cautery has been used to control bleeding since ancient times. The earliest account in Western literature of its use in the control of gastrointestinal haemorrhage is found in Hippocrates ${ }^{1}(460-380 \mathrm{BC})$ who used red hot irons to control bleeding from haemorrhoids. Cautery was first used ${ }^{2}$ to treat bleeding from gastric ulcers in man in the 1880's by Mikulicz and Kuster during early operative attempts to control gastrointestinal bleeding. Physiological studies with rapidly alternating current introduced by d'Arsonval ${ }^{3}$ in 1891 and clinical studies of

Address for correspondence: Dr C P Swain, The Rayne Institute, 5 University Street, London WC1E 6JJ.

Received for publication 30 March 1984 diathermy introduced by Nagelschmidt ${ }^{4}$ in 1907 came to establish monopolar electrocautery as an effective adjunct to general surgery. ${ }^{56}$ Although electrocautery has been occasionally used in conjunction with rigid endoscopes in the gastrointestinal tract since the 1920 's ${ }^{7}$ systematic study of electrocautery as an endoscopic method of controlling gastrointestinal haemorrhage dates from the studies of Youmans ${ }^{8}$ and Blackwood and Silvis. ${ }^{9}$

Monopolar electrocoagulation applied directly to tissue is highly effective in terminating bleeding in experimental canine ulcers, ${ }^{10-16}$ has been widely used in uncontrolled human studies ${ }^{17-21}$ and a small controlled study ${ }^{22}$ suggests that it may be effective in diminishing the rebleeding rate and need for surgery in patients with non-bleeding 'visible vessel'. The high incidence of full thickness tissue damage in animal experiments, however, suggests that it might cause perforation in man, which has been reported in some ${ }^{1323}$ clinical series. The application of a dry 
monopolar electrode to a bleeding point can cause thermal adherence of a coagulum to the probe, which may be avulsed from the bleeding point as the probe is withdrawn with a consequent increase in bleeding. ${ }^{13}$

Three electrode systems have been recently introduced to overcome these problems of tissue adherence and deep tissue damage. The introduction of a conductive interfacial film of liquid between the monopolar electrode and the tissue may abolish tissue adherence and diminish tissue damage. ${ }^{24-27} \mathrm{~A}$ bipolar probe,$^{15} 16$ where current passes through a small area of tissue between two or more electrodes on the same probe, appears to produce less full thickness damage than dry monopolar eletrocoagulation. A heater probe incorporates in its brass tip a semiconductor device which raises its temperature to a constant $160^{\circ} \mathrm{C}$ which is maintained until a precise amount of energy has been delivered to tissue; this device may cause less damage than monopolar electrocoagulation, has a non-stick coating and may be safer than devices that use rapidly alternating current since no electricity passes through the patient. ${ }^{28}$

Thus there are four main types of endoscopic electrode reported to be of value in treating bleeding ulcers in experimental animals or man. There has been no controlled comparison of all four electrodes.

\section{Methods}

\section{MATERIAL (Fig. 1)}

The dry monopolar electrode (M) used in this study (model 80-7051, Cameron Miller) had a rounded metal tip ( $2.2 \mathrm{~mm}$ diameter) with a central washing

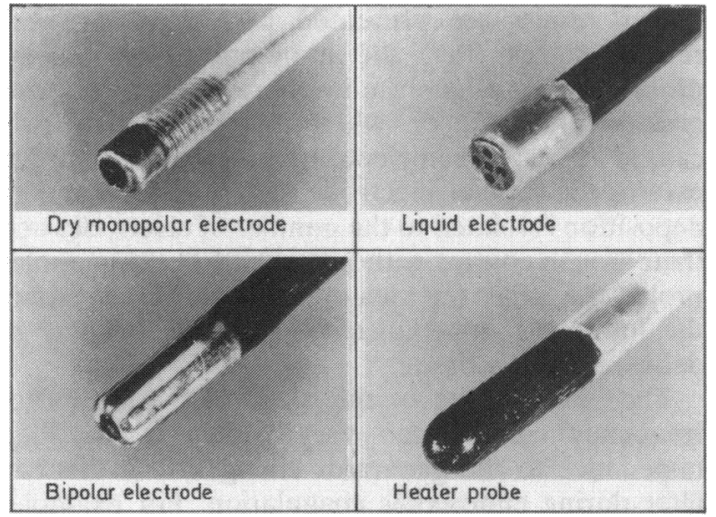

Fig. 1 Views of the probe tips: $M=$ Dry monopolar electrode, $L=$ Liquid electrode, $B=$ Bipolar electrode, $H=$ Heater probe. channel of $0.8 \mathrm{~mm}$ diameter. The liquid electrode used (L) (model 61000, Karl Storz, Tutlingen) was a flat-ended cylinder perforated with $5 \times 0.4 \mathrm{~mm}$ diameter holes through which the conductive liquid can pass. This electrode was slightly modified, being insulated to the tip to ensure that a constant surface area was presented to the target tissue and to diminish lateral dissipation of current. The bipolar electrode (B) ('Bicap' ACMI) was a $2.5 \mathrm{~mm}$ diameter probe with a rounded tip and central washing channel. Its six electrodes with alternating polarities lay in a pattern that allowed at least two electrodes to be in contact with tissue, at whatever angle the probe was applied. The heater probe $(\mathrm{H})$ (Auth, University of Washington, Seattle) was a 2.5 $\mathrm{mm}$ brass cylinder with a rounded tip encapsulating an electronically controlled heat source and temperature regulator. The brass tip was coated with a non-stick silicone coating. Because the centre of the tip contains sensitive electronic components, washing channels were cut into the periphery of the proximal end of the metal tip. All these electrodes had a washing facility for clearing blood and debris from the bleeding area and all could be passed through standard endoscopes with a biopsy channel of $2.8 \mathrm{~mm}$ or greater diameter (Fig 2).

\section{ELECTROSURGICAL GENERATORS}

The generator used for the devices using radiofrequency current (M, L, B) was the Erbotom T 175 manufactured by Erbe Elektromedizin, Tubigen, West Germany. Its monopolar coagulation waveform was a variable intensity $550 \mathrm{kHz}$ sinusoid modulated at $20 \mathrm{kHz}$ to give a constant crest factor of 6.5 approximately. Maximum output power was 160 watts into either $500 \mathrm{ohm}$ or $200 \mathrm{ohm}$

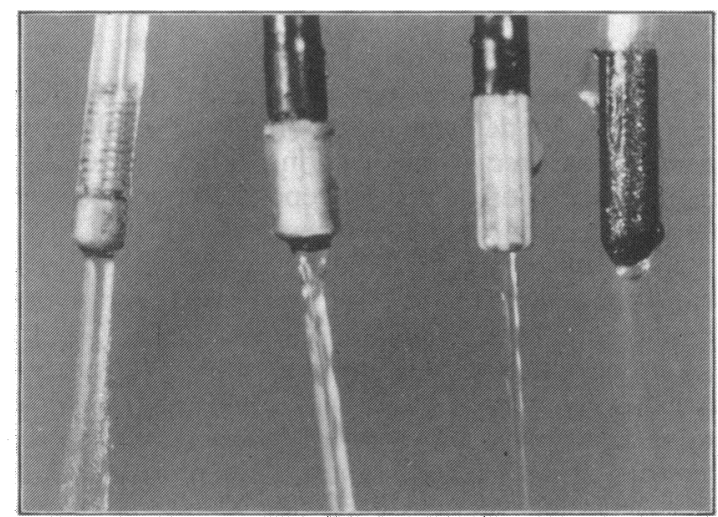

Fig. 2 Washing channels of the four electrodes in action. 
impedance. The bipolar output used with the bipolar electrode delivered a maximum output power of $50 \mathrm{~W}$ into $125 \mathrm{ohm}$ load impedance.

\section{ANALOGUE COMPUTER}

To overcome the difficulty of quantifying or controlling energy delivered to tissue during electrocoagulation, one group has applied analogue computer techniques. ${ }^{14} 15$ For our study, an analogue computer was designed and constructed in the Department of Medical Physics at University College Hospital. This computer ${ }^{27}$ which was connected between the generator and the electrodes using radiofrequency current, sensed the voltages and currents in the electrode leads and by utilising conventional analogue computer techniques, performed the necessary mathematical operations to give direct readings of real power, energy deposition and application time.

\section{EXPERIMENTAL ULCER MODEL}

Acute ulcers of a reproducible $\operatorname{size}^{29}(1 \mathrm{~cm}$ diameter approx.) were made in canine gastric mucosa using a suction biopsy capsule, the Quinton ulcer maker. Ulcers made by this device cut into the vascular submucosa without damaging the muscularis propia. They cut through an average of five small bleeding points which ooze briskly and do not stop spontaneously in heparinised dogs (100 IU/kg repeated at one hour); spurting arterial haemorrhage was observed in about $5 \%$ of the ulcers.

\section{STATISTICAL METHODS}

The significance of observed differences was assessed by $\chi^{2}$ analysis ${ }^{30}$ with Yates' continuity correction $^{31}$ and by Student's $t$ test to test the differences between means. ${ }^{32}$

\section{EXPERIMENTAL DESIGN}

A preliminary in vitro study was carried out on fresh pig's liver to determine the effects of application force, measured using a spring force gauge, and probe angulation on energy deposition per pulse and surface area of coagulative necrosis.

In an in vitro study, 160 experimental ulcers were randomly allocated to treatment with dry monopolar (M), liquid monoploar (L), bipolar electrocoagulation $(B)$, heater probe $(H)$ or to control. Randomisation was performed using a random numbers table, equal numbers of ulcers in all dogs being randomised to treatment with each of the four electrodes in each dog. There were two control ulcers in each dog.

Experimental gastric ulcers were formed with a Quinton ulcer maker in eight female greyhounds
$(19-25 \mathrm{~kg})$. Anaesthesia was induced and maintained with intravenous sodium pentobarbital, respiration was maintained artificially, core temperature was monitored and controlled and fluid losses were replaced with normal saline. Via a midline laparotomy incision, an anterior gastrostomy provided access to gastric mucosa. Twenty to 30 acute bleeding ulcers were made in acute experiments (four animals). All control ulcers in these heparinised animals continued to bleed for a period far exceeding the longest treatment period for any ulcer. After the experiment, the stomach was removed and pinned out under formalin. After fixation, each ulcer was identified, excised and sectioned into $1 \mathrm{~mm}$ slices with a multi-section tissue sampling device. ${ }^{32} \mathrm{~A}$ dissecting microscope was used to determine the ulcer slice with the deepest thermal injury. ${ }^{33}$ This slice was embedded in paraffin, sectioned at $5 \mu \mathrm{m}$ and stained with haematoxylin and eosin.

All microscopic sections were analysed by two of us who were unaware of the type of ulcer treatment. For survival studies in four greyhounds, the operative technique was modified in order to enhance the chance of survival. Only 10 ulcers were made in each stomach. Eight were randomised to treatment with the four probes, two ulcers to control, the dose of heparin was omitted. The stomachs were removed at seven days after the operation.

\section{Results}

In an in vitro study carried out on fresh liver, the effect of electrode force (weak force $=0.03$ Newtons and strong force $=0 \cdot 12 \mathrm{~N}$ ), and electrode angulation (at $90^{\circ}, 45^{\circ}$, and laid flat $0^{\circ}$ ) were related to energy deposition and the surface area of consequent coagulative necrosis at optimal settings.

Our results are presented in Figure 3. These results suggest that the monopolar and bipolar probes show an increase in energy deposition with greater pressure, or when increased angulation caused an increase in electrode tissue contact. In the case of the bipolar electrode, the change in energy deposition is related to the number of electrodes and their area in contact with tissue; with the monopolar probe, the larger the area of electrode tissue contact the lower the impedance thus varying the energy delivered to the tissue.

The performance of the electrodes using radiofrequency current can vary widely if the load impedance to the generator changes, and this can alter during endoscopic coagulation. For example, under different conditions of application force, the area of the electrode-tissue contact and consequently the impedance presented to the generator 

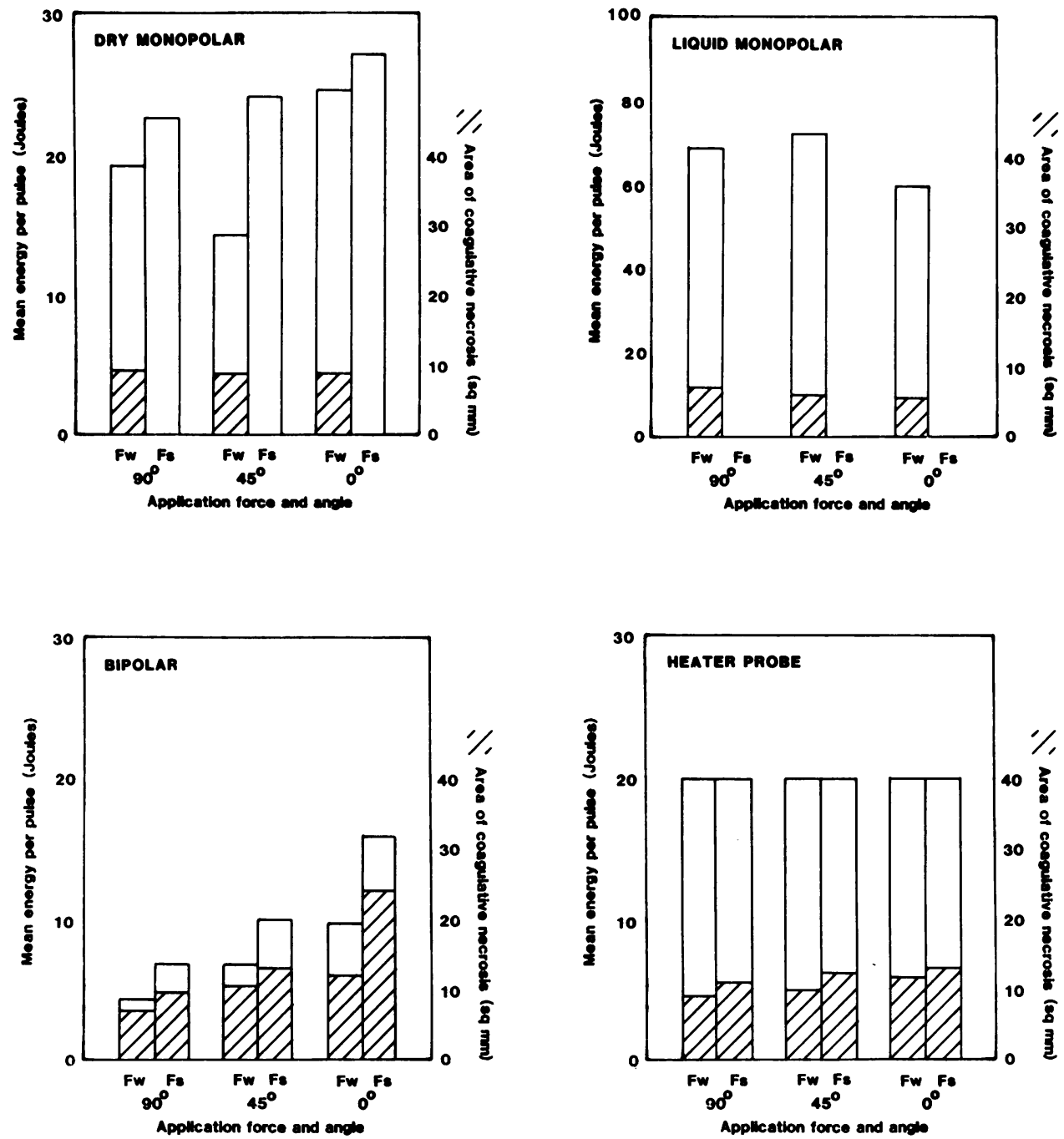

Fig. 3 Studies of application force $(0.03 N(F w)$ or $0.12 N(F s))$ and electrode angulation $\left(90^{\circ}, 45^{\circ}\right.$ or $0^{\circ}$ (lying flat $\left.)\right)$ on energy deposition and area of coagulative necrosis.

may vary widely and affect endoscopic coagulative performance. The power delivered by a radiofrequency generator set at a constant intensity varies in a non-linear fashion (Fig.4) with the load impedance.

Depending on the characteristics of the generator used, altered load impedance will result in a decrease or an increase in energy delivered to tissue as shown in Figure 4. With the generator used in this study, there was a reduction in load impedance with a consequent increase in energy deposition.

Paradoxically, it is possible with firm pressure on the monopolar electrode to achieve very little coagulative necrosis despite an increase in energy deposition. This is because the energy is deposited over too great an area to raise the tissue temperature to a level sufficient for coagulation necrosis. The magnitude of the current density which determines the degree of heating within the tissue is in this case too small. Energy deposition at different angles with the liquid electrode showed little variation; high pressure with the liquid electrode abolishes the liquid film, consequently the effect of pressure with this electrode was not studied. The 


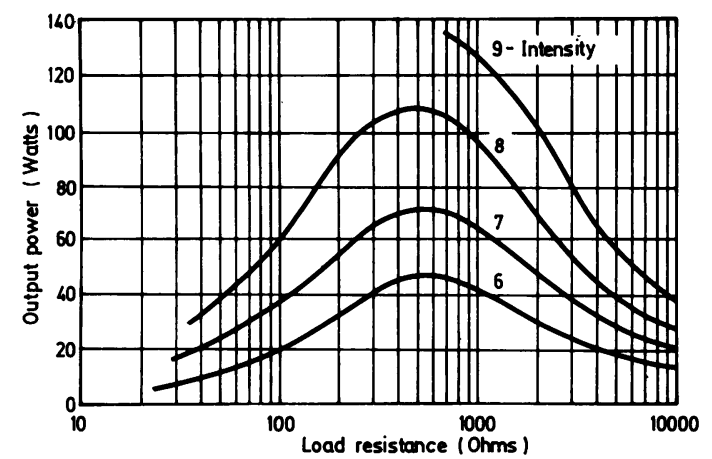

Fig. 4 Variation of generator output power with load resistance for constant intensity settings.

heater probe delivered the same amount of thermal energy and produced more or less the same area of coagulative necrosis at low and high pressures and at different angles because the energy is preset and independent of tissue impedance and contact area.

\section{EFFICACY}

The results in Table 1 show that all four electrodes were effective in that all bleeding ulcers were successfully coagulated while all control ulcers continued to bleed for 10 minutes or longer in these heparinised animals. Comparisons of the mean number of pulses required to achieve haemostasis with the different electrodes, however, suggests that the bipolar electrode was significantly inferior to the others in that it required almost twice the mean number of pulses to achieve haemostasis.

\section{SAFETY}

No perforations were caused by the treatment of these ulcers. A range of lesser patterns of tissue damage, however, may be observed and the safety of different thermal methods may be assessed by comparing the extent of tissue damage detected at histology. When the incidence of full thickness damage (FTD) was assessed at histology, the results suggested that the heater probe (20\% FTD) and bipolar probe (24\% FTD) were significantly safer than the dry monopolar (69\% FTD) and the liquid monopolar (58\% FTD) electrodes.

TISSUE ADHERENCE AND STICKING (Table 2)

All probes except the liquid monopolar electrode were susceptible to contamination with dried blood and tissue. The incidence of 'sticking' defined as increased bleeding after removal of the probe from the bleeding point was, however, low in this study. Tissue adherence diminished the coagulative performance of these electrodes, which had to be wiped clean when tissue adherence was severe. Efficacy however, appeared relatively independent of 'sticking' in this model, subsequent pulses were able to terminate bleeding in all ulcers in which this phenomenon was observed.

\section{REPRODUCIBILITY OF ENERGY DEPOSITION}

The devices using radiofrequency current were compared for reproducibility of energy deposition per pulse at optimal settings as used during the treatment of these bleeding ulcers. The liquid electrode performed most reproducible delivery $66.4 \pm 4.3 \mathrm{~J}$. The bipolar electrodes $(17 \cdot 5 \pm 2 \cdot 7)$ delivered energy more reproducibly than the dry monopolar electrode $(22 \cdot 9 \pm 5 \cdot 4 \mathrm{~J})$. The heater probe was preset to deliver $15 \mathrm{~J}$ per pulse.

\section{Discussion}

The four endoscopic probes studied proved highly effective in terminating bleeding in this experimental bleeding ulcer model. Because bleeding was stopped in all ulcers in less than 20 pulses, quantification of relative efficacy was based on a comparison of the number of pulses required to do so. An increase in the number of pulses required to achieve haemostasis would be a technical disadvantage, prolonging endoscopy and requiring greater operator skill, as each pulse must be perfectly

Table 1 Efficacy and safety of the four probes

\begin{tabular}{llll}
\hline & $\begin{array}{l}\text { Optimal pulse } \\
\text { energy } \\
\text { (Joules) }\end{array}$ & $\begin{array}{l}\text { Mean } \\
\text { Ulcers } \\
\text { coagulated }\end{array}$ & $\begin{array}{l}\text { Full thickness } \\
\text { damage at } \\
\text { histology (\%) }\end{array}$ \\
\hline Dry monopolar (Cameron Miller) & 20 & $35 / 35$ & $6 \cdot 3 \pm 4 \cdot 4$ \\
Liquid monopolar (Storz) & 70 & $35 / 35$ & $6 \cdot 1 \pm 2 \cdot 1$ \\
Bipolar (ACMI Bicap) & 17 & $35 / 35$ & $10 \cdot 3 \pm 7 \cdot 6$ \\
Heater probe (D Auth) & 15 & $35 / 35$ & $5 \cdot 3 \pm 2 \cdot 3$ \\
\hline
\end{tabular}

The bipolar probe required significantly more pulses $(p<0.02)$ to achieve haemostasis than the other three probes. The heater probe and bipolar electrode caused significantly less tissue damage $(p<0.01)$ than monopolar electrocoagulation used dry or with a liquid interface. 
Table 2 Electrode tip contamination and 'sticking'

\begin{tabular}{lrrrrr}
\hline & & & \multicolumn{3}{c}{ Total } \\
& Clean & Mild & Severe & ulcers & Sticking \\
\hline Dry monopolar & 2 & 27 & 6 & 35 & $2 / 35$ \\
Liquid monopolar & 34 & 1 & 0 & 35 & $0 / 35$ \\
Bipolar & 2 & 26 & 7 & 35 & $3 / 35$ \\
Heater probe & 1 & 24 & 10 & 35 & $5 / 35$ \\
\hline
\end{tabular}

Clean $=$ no tissue adherent to electrode.

Mild $=<50 \%$ of electrode tip covered with adherent tissue.

Severe $=>50 \%$ of electrode tip covered with adherent tissue.

Sticking $=$ the phenomenon of increased bleeding observed after

removal of an adherent electrode form a bleeding point.

aimed. The bipolar probe was less effective than the other three probes tested in this regard, but was able to stop bleeding in all the ulcers treated.

Some reservations should be made in extrapolating from these results of efficacy in experimental ulcers to the performance of these electrodes in bleeding ulcers in man. In the experimental ulcer, the arteries are all small submucosal vessels cleanly cut, without pathological change. In the bleeding ulcer in man $^{34}$ the artery may be submucosal in acute ulcers, but half will be chronic ulcers penetrating larger serosal vessels; pathological arterial degeneration is common; effective vessel contraction may be vitiated by the presence of scar tissue.

These electrodes appeared relatively safe in these studies at the chosen settings. Perforation secondary to thermal injury which may be immediate or delayed, is the most serious hazard associated with the use of these electrodes. No perforations occurred in these studies of our or other groups ${ }^{14-16}$ 242528 in standard experimental gastric ulcers using these devices at optimal settings with light pressure, although full thickness tissue damage at histology is common. Clinical perforations, however, have been reported in patient series treated with monopolar electrocoagulation. ${ }^{13}{ }^{23}$ The high incidence of full thickness tissue damage with dry monopolar electrocoagulation has stimulated the study of alternative means of electrocoagulation which are potentially safer. It seems reasonable to assume that a lower incidence of full thickness tissue damage will reduce the risk of perforation when these devices are used in man. Bipolar electrocoagulation and the heater probe both produced significantly lower incidences of full thickness damage when compared with monopolar electrocoagulation used either dry or with liquid. Minor hazards to the patient and endoscopist because of a poorly applied patient plate or aberrent earthing ${ }^{35}$ are reduced by using bipolar electrocoagulation or heater probe.

It is likely that unstable clot or aneurysm at a bleeding point may make the problem of sticking more serious in the clinical setting than in this ulcer model; careful clinical observation on this point would be of value in future clinical studies. The liquid electrode was highly effective in abolishing the problem of tissue adherence and sticking, but even this device and non-contact devices such as lasers ${ }^{36}{ }^{37}$ are still capable of causing a non-bleeding vessel to bleed when treated. Only one device, the heater probe, had a non-stick silicone coating. Most non-stick coatings are electrical insulators and are therefore unsuitable. for use with electrodes using radiofrequency current; they are also poor thermal conductors, hence the coating on the heater probe is necessarily thin and may be damaged by passage though the biopsy channel of an endoscope. The efficacy of this probe was not adversely affected by damage to the coating. An electrode contaminated with adherent 'enamel' should be withdrawn and gently cleaned before further pulses are delivered to tissue.

The physical differences between the electrodes will dictate differences in endoscopic technique during their use. The extremity of the tip of the heater probe must be placed where the centre of the thermal effect is required. The bipolar electrode performs best when lying flat but delivers a wide range of energies at the same generator setting depending on the number of electrodes in contact with tissue. Dry monopolar electrocoagulation may be less effective at extremes of angulation and pressure. The delicate electronics and coating of the heater probe may limit the lifespan of this device when compared with the rugged monopolar devices and will be more expensive. Shorting is a problem inherent with bipolar electrodes; it is difficult to isolate two high voltage conductors in a $2.5 \mathrm{~mm}$ diameter device over a metre long with a central washing channel. A guide to the relative merits of the four electrocautery systems using a five star rating is presented in Table 3 .

Before these devices can be recommended for widespread use, it is essential that their efficacy and safety are tested in properly designed controlled clinical trials. Which trials should be undertaken? A trial of dry monopolar electrocoagulation against control would be valuable, for this device has been widely used and its efficacy is supported by some controlled data. If this device were to prove both effective and safe clinically, then its simplicity and cheapness would make it the endoscopic method of choice. In our opinion, it would be reasonable to consider undertaking controlled trials with any of the other devices all of which offer some attractive feature. The ability of the liquid electrode to abolish sticking may be an important clinical advantage, the 
Table 3 A consumer's guide to the relative merits of the four electrocautery systems using a five star rating

\begin{tabular}{|c|c|c|c|c|}
\hline & $\begin{array}{l}\text { Monopolar } \\
\text { electrode }\end{array}$ & $\begin{array}{l}\text { Liquid } \\
\text { electrode }\end{array}$ & $\begin{array}{l}\text { Bipolar } \\
\text { electrode }\end{array}$ & $\begin{array}{l}\text { Heater } \\
\text { probe }\end{array}$ \\
\hline Efficacy & $* * * *$ & $* * * *$ & $* *$ & $* * * *$ \\
\hline $\begin{array}{l}\text { Safety (risk of full } \\
\text { thickness tissue } \\
\text { damage) }\end{array}$ & $* *$ & $* *$ & $* * *$ & $* * *$ \\
\hline Tissue adherence & $* *$ & $* * * * *$ & $* *$ & $* *$ \\
\hline Durability & $* * * *$ & $* * * *$ & $* *$ & $* *$ \\
\hline Reliability & $* * * *$ & $* * *$ & $* *$ & $* *$ \\
\hline Electrical safety & $* * *$ & $* * *$ & $* * * *$ & $* * * * *$ \\
\hline \multicolumn{5}{|l|}{ Cost $(f)$} \\
\hline $\begin{array}{l}\text { Recommended } \\
\text { generator }\end{array}$ & 795 & 1736 & 1830 & 1800 \\
\hline Probe & 113 & 74 & 120 & 267 \\
\hline
\end{tabular}

bipolar probe was safe and easy to use and is cheaper than the heater probe. The heater probe, however, combined high efficacy with low tissue damage and in this study appeared the most promising electrode tested.

This study was supported by a Department of Health and Social Security Grant (A6). The authors thank $\mathrm{Mr} \mathrm{C}$ Keast and the Department of Experimental Pathology at UCH, and Professor C G Clark for their encouragement, Erbe Electromedizin and American Cystoscope Company Inc for the loan of electrosurgical generators and Miss Julie Forster for typing the manuscript.

\section{References}

1 Hippocrates. The genuine works of Hippocrates. Translated by Frances Adams. London: Sydenham Society, 1849: vol II: 827 and 829.

2 Dieulafoy G. Exulceratio Simplex. Bull Acad Med 1898; 39-40: 49-84.

3 d'Arsonval MA. Action physiologique des courants alternatifs. C R Soc Biol (Paris) 1891; 3: 283-7.

4 Nagelschmidt F. Ueber diathermie (Transthermic Thermopenetration) Münch med Wochenschr. 1909; 56: $2575-77$.

5 Bovie WT, Cushing H. Electrosurgery as an aid to the removal of antracervical tumours. Surg Gynecol Obstet 1928; 47: 751-84.

6 Kelly HA, Ward GE. Electrosurgery. Philadelphia: Saunders, 1932.

7 Abel AL. Oesophageal obstruction, its pathology, diagnosis and treatment. London: Oxford Medical Publications, 1929.

8 Youmans CR, Patterson M, McDonald DF, Derrick JR. Cytoscopic control of gastric haemorrhage. Arch Surg 1970; 100: 721-3.

9 Blackwood WD, Silvis SE. Gastroscopic electro- surgery. Gastroenterology 1971; 61: 305-14.

10 Pesch HJ, Koch H, Classen M. Experimentalle und histologische Untersuchungen zur Elektrokoagulation bluntender Lasionen im oberen Gastrointestinaltrakt. Leber Magen Darm 1973; 3: 172-6.

11 Papp JP, Fox JM, Wills HS. Experimental electrocoagulation of dog gastric mucosa. Gastrointest Endosc 1975; 22: 27-8.

12 Mann SK, Mann NS. Endoscopic electrocoagulation of superfical bleeding lesions in canine esophagus, stomach and duodenum. Am J Gastroenterol 1978; 29: 23-9.

13 Papp JP. Endoscopic control of gastrointestinal haemorrhage. Florida: CRC Press, 1981: 31-42.

14 Piercey J, Auth DC, Silverstein FE et al. Electrosurgical treatment of experimental bleeding canine gastric ulcers: development and testing of a computer control and a better electrode Gastroenterology 1978: 74: 527-34.

15 Protell RL, Gilbert DA, Jensen DM et al. Computer assisted electrocoagulation: bipolar vs monopolar in the treatment of experimental canine gastric ulcer bleeding. Gastroenterology 1978; 74: 232-9.

16 Johnston JH, Jensen DM, Mautner W. Comparison of endoscopic electrocoagulation and laser photocoagulation of bleeding canine gastric ulcers. Gastroenterology 1982; 82: 904-10.

17 Sugawa C, Shier M, Lucas CE, Walt AJ. Electrocoagulation of bleeding in the upper gastrointestinal tract. Arch Surg 1975; 110: 975-9.

18 Volpicelli NA. McCarthy JD, Bartlett JD, Badger WF. Endoscopic electrocoagulation. Arch Surg 1978; 113: 483-6.

19 Papp JP. Endoscopic electrocoagulation of actively bleeding arterial upper gastrointestinal lesions. $A m J$ Gastroenterol 1979; 71: 516-21.

20 Gaisford WD. Endoscopic electrohaemostasis of active upper gastroinestinal bleeding. Am J Surg 1979; 137: 47-53.

21 Wara P, Hojsgaard A, Amdrup E. Endoscopic electrocoagulation - an alternative to operative haemostasis in active gastro-duodenal bleeding? Endoscopy 1980; 5: 237-41.

22 Papp JP. Endoscopic electrocoagulation in the management of upper gastrointestinal tract bleeding. Surg Clin North Am 1982; 62: 797-806.

23 Koch H, Pesch HJ, Bauerle H, Fruhmorgen P, Rosch W, Classen M. Erst Experimentelle Untersuchungen und klinische Erfahrungen zur Elektrokoagulation bluntender Lasionen im oberen Gastrointestinaltrakt. In: Ottenjann R, ed. Fortschritte der Endoskopie, Stuttgart: Schattauer-Verlag, 1973; 69-71.

24 Reidenbach HD, Bodem F, Fruhmorgen P, Schroeder $G$, Lex P, Kaduk B. Eine neue methode zur Endoskopischen Hochfrequenz-koagulation von Schleimhautdefekten. Biomed Tech (Berlin) 1978; 4: 71-4.

25 Matek W, Fruhmorgen P, Kaduk B, Reidenbach HD, Bodem F, Demling L. Modified electrocoagulation and its possibilities in the control of gastrointestinal bleeding. Endoscopy 1979; 11: 553-8.

26 Matek W, Fruhmorgen P, Kaduk B, Reidenbach HD, 
Bodem F, Demling L. The healing process of experimentally produced bleeding lesions after haemostatic electrocoagulation with simultaneous instillation of water. Endoscopy 1980; 12: 231-6.

27 Swain CP, Mills TN, Dark JM. A comparative study of the safety and efficacy of liquid and dry monopolar electrocoagulation in experimental canine bleeding ulcers using computerised energy monitoring. Gastroenterology 1984; 86: 93-103.

28 Protell RL, Rubin C, Auth D et al. The heater probe: a new endoscopic method for stopping massive gastrointestinal bleeding. Gastroenterology 1978; 74: 257-62.

29 Protell RL, Silverstein FE, Piercey J, Dennis M, Sprake W, Rubin CE. A reproducible animal model of acute bleeding ulcer: the "ulcer maker". Gastroenterology 1976; 71: 961-4.

30 Pearson $\mathrm{K}$. On the criterion that a given system of deviations from the probable in the case of a correlated system of variables is such that it can be reasonably supposed to have arisen from a random sampling. Phil
Mag 1900; Ser V; 1: 157-75.

31 Yates $\mathrm{F}$. Contingency tables involving small numbers and the $\chi^{2}$ test. $J R$ Stat Soc B, (Suppl) 1934; 1: 217-35.

32 "Student" (Gosset WS). The probable error of a mean. Biometrika 1980; 6: 1-25.

33 Martin L, Peoples J, Protell RL et al. The multisection tissue slicer. Gastrointes Endoscopy 1979; 25: 61-2.

34 Swain CP, Bown SG, Storey DW, Salmon PR, Kirkham JS, Northfield TC. The nature of the bleeding point in massively bleeding peptic ulcers. Gastroenterology 1983; 84: 1327.

35 Taunton JC. Surgical diathermy - a review. Med Engineer Technol 1981; 5: 175-83.

36 Vallon AG, Cotton PB, Laurence BH, Armengol Miro JR, Salford Oses JC. Randomised trial of endoscopic argon laser photocoagulation in bleeding peptic ulcers. Gut 1981; 22: 228-33.

37 Swain CP, Bown SG, Storey DW, Northfield TC, Kirkham JS, Salmon PR. Controlled trial of argon laser photocoagulation in bleeding peptic ulcers. Lancet II; $1981 ; 1313-16$. 